\title{
窒化アルミニウム多結晶基板の湿式研磨における表面損傷の電子顕微鏡観察
}

\author{
高橋 裕・菊池正雄・鈴木重信* ·須賀唯知** \\ 東京大学工学部精密機械工学科, 113 東京都文京区本郷 7-3-1 \\ *職業訓練大学校福祉工学科, 229 神奈川県相模原市相模 1960 \\ **東京大学先端科学技術研究センター, 153 東京都目黒区駒場 4-6-1
}

\section{Transmission Electron Microscopy of Surface Damages Resulting from Wet Polishing in a Polycrystalline Aluminum Nitride Substrate}

\author{
Yutaka TAKAHASHI, Masao KIKUCHI, Shigenobu SUZUKI* and Tadatomo SUGA** \\ Department of Precision Engineering, Faculty of Engineering, University of Tokyo, 7-3-1, Hongo, Bunkyo-ku, Tokyo 113 \\ *Department of Rehabilitation Engineering, Institute of Vocational Training, 1960, Sagami, Sagamihara-shi, Kanagawa 229 \\ **Research Center for Advanced Science and Technology, University of Tokyo, 4-6-1, Komaba, Meguro-ku, Tokyo 153
}

[Received January 29, 1991; Accepted April 19, 1991]

\begin{abstract}
AlN polycrystalline specimens were wet-polished with $\mathrm{Al}_{2} \mathrm{O}_{3}$ and $\mathrm{Cr}_{2} \mathrm{O}_{3}$ abrasives. A flat surface with a roughness of $100 \mathrm{~nm}$ was achieved, while the surface layer was heavily damaged. High-voltage electron microscopy revealed that the damaged and/or dislocated layer was about $0.5 \mu \mathrm{m}$ thick and a few dislocations propagated deeper. The source of dislocation such as free surface and grain boundary was discussed.
\end{abstract}

Key-words : AlN, Wet polishing, Surface damage, $\mathrm{Al}_{2} \mathrm{O}_{3}$ abrasive, $\mathrm{Cr}_{2} \mathrm{O}_{3}$ abrasive, Transmission electron microscopy, Dislocation

\section{1. 緒 言}

LSI の小型化，高密度化に伴い，セラミックス基板に対 して種々の厳しい要求が課されるようになってきた。最も 重要な特性は高抵抗，高絶縁性，低誘電損などの電気的性 質であるが，高放熱性，低熱膨張率，高温安定性などの熱 的性質も重要な因子である1)。このような要請を満たす材 料としてアルミナ(サファイア)が従来用いられてきたが， 近年，これを凌駕する候補として窒化アルミニウム (AlN) が注目されている2),3). 特に，熱伝導度は $\mathrm{Al}_{2} \mathrm{O}_{3}$ よ り約 1 けたも大きく4),5)， $\mathrm{BeO}$ のような毒性を持たないこ とが有利な点として挙げられる.

$\mathrm{AlN}$ は金属と同程度の熱伝導度を有するが，絶縁体で あるためフォノンがその担い手となる。このため， O , Fe， $\mathrm{Si}$ などの不純物原子 (点欠陷) ${ }^{6), 7)}$ や転位 ${ }^{8)}$, 積層欠 陥8） 10)，粒界11）（線欠陥，面欠陥）の存在は熱伝導度に 敏感に影響し，そのプロセッシングに括いては欠陥の発生 に留意しなければ高放熱特性を得ることができない.

AlN を厚膜あるいは薄膜回路用の基板として用いる場 合，あらかじめポリシングを施し平滑面を出す必要がある. ところが,

（1）結晶構造が六方晶系であるため除去速度に異方性 があり，多結晶材料では各結晶粒で段差を踏む（表面粗さ への影響),
（2） $\mathrm{AlN}$ 多結晶体は粒界強度が弱く，結晶粒の脱離が 起こりやすい（表面損傷の発生）,

などの問題点を抱えているため, 効率的な $\mathrm{AlN}$ 基板のポ リシングは困難な状況にある。

最近, 著者らは酸化物砥粒により形成したポリシングデ ィスクによるセラミックスの研磨法を開発した ${ }^{12)}$ 。この 方法を AlN 多結晶体に適用したところ，極めて効率良く 研磨されることが示された ${ }^{13)}$ ，しかしながら，その加工 表面の微細組織，特に加工による表面損傷については不明 なままにされている．本研究においては透過電子顕微鏡 （TEM）により研磨に伴う表面損傷を観察したので，その 結果について報告する。

\section{2. 実験方法}

\section{1 研磨条件}

供試材は一片約 $6 \mathrm{~mm}$, 厚さ $1 \mathrm{~mm}$ の $\mathrm{AlN}$ 多結晶体（徳 山曹達, シェイパル SH-15) である. 研磨機はニューダ イヤラップ ML-461 (マルトー) を，研磨ディスクとし ては $\alpha-\mathrm{Al}_{2} \mathrm{O}_{3}$ （平均粒径 $2 \mu \mathrm{m}$ ) ないしは $\mathrm{Cr}_{2} \mathrm{O}_{3}$ （平均粒 径 $2 \mu \mathrm{m})$ にフェノール樹脂をバインダーとして $5 \%$ 加え， 成形したものの 2 種類を用いた.

試料小片を熱ワックスによりサンプルホルダーに張り付 け，水道水による湿式下に抢いて加工圧 $0.17 \mathrm{MPa}$ ，加工

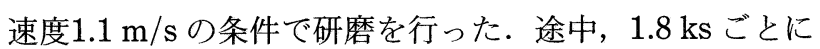
試料厚みを測定して除去速度を調べた. 研磨後, アルコー ル，アセトン中で良く超音波洗浄し，表面粗さ測定（触針 式表面粗さ計タリステップ，ランクテーラーボブソン社） 及び TEM 観察に供した。

\subsection{TEM 試料作製法}

TEM 観察のための薄膜試料は 2 種類の方法で作製し た.

断面観察 : 研磨方向に直交する方向からの観察より，加 工層の深さ方向に関する情報が得られる. 薄膜試料は通常 の断面 TEM 法14)により作製した.

(1) 研磨面を向い合せにしてアラルダイトで張り付け 
る。

（2）ダイヤモンドホイールを用いて薄板を切り出す.

（3）エメリ一紙を用いて約0.1 $\mathrm{mm}$ の厚みまで機械的 に研磨した後, 単孔メッシュに張り付ける。

（4）イオンシニング（加速電圧 $4 \sim 5 \mathrm{kV}$ ）により最終 研磨を行う。

研磨方向からの観察 : 断面観察の結果に研磨方向办らの 観察結果を付け加えることにより，欠宿分布の 3 次元的 描像が明らかになる。この試料はバックシニング法により 作製した。

(1) 研磨面と逆側から厚さ約 $0.1 \mathrm{~mm}$ まで機械研磨を 行い，単孔メッシュに張り付ける.

(2) 研磨面の逆側のみからイオンシニングを施す。

これらの試料は JEM-1250超高圧電子顕微鏡（加速電圧 $1000 \mathrm{kV}$ ）を用いて観察を行った。

\section{3. 結 果}

\section{1 表面粗さの測定結果}

図 1(a)k除去厚久の時間依存性を，図 1(b)に研磨され た試料の表面粗さ測定の結果を示す. $\mathrm{Al}_{2} \mathrm{O}_{3}$ 及び $\mathrm{Cr}_{2} \mathrm{O}_{3}$ の いずれの砥粒においても $10 \mu \mathrm{m} / \mathrm{ks}$ 程度の高加工能率が得 られて抢り，汃表面粗さ $R_{\max }$ は100 nm 以下であるこ とが分る。

一方，図 2 にはこの試料のバルク内の組織を示す。粒径 はお抢よそ $3 \mu \mathrm{m}$ 程度であり，粒内には積層不整や転位な どの欠陥はほとんど見られない，AIN 多結晶体において 粒界の強度は非常に低く，粒界破壊しやすい性質を持つ （図 3，各粒の電子線回折からクラックの上下で結晶方位 が異り，粒界割れであることが確認されている)。しかし ながら測定された表面粗さは結晶粒径よりはるかに小さ く, 前述の研磨工程では結晶粒の豩離が生じていないこと を意味している。

したがって，以上の結果だけからは $\mathrm{Al}_{2} \mathrm{O}_{3}$ 及び $\mathrm{Cr}_{2} \mathrm{O}_{3}$ 砥粒の湿式研磨は非常に優れた方法であるように見える。 ところが以下の TEM 観察から分かるように表面近傍には 著しい損傷が生じていた。

\section{$3.2 \mathrm{Cr}_{2} \mathrm{O}_{3}$ 䂠粒で研磨した試料の断面観察の結果}

图 4 Kは $\mathrm{Cr}_{2} \mathrm{O}_{3}$ 砥粒で研磨した試料の断面観察の結果 を示す。この写真においては試料端近傍はバルクの組織と 同じであり研磨面最表面には全く知陷が存在しない上うに 見えるが，これは薄膜作製時に生じたアーティファクトで あることを注意しておかねばならない。つまり，断面試料 の作製においては貼り合わせた部分から優先的にイオンエ ッチングを受けるため，この場合はすでに最表面は削れて しまっている。

研磨最表面を観察するためには接着剤が付いている部分 を観察するのが安全である。図 5 ではコントラストの関係 で明確には見えないが，試料端上部にエポキシ樹脂が唇く 付着し，最表面を示す目印となる。このような部分は図 4のような場合と比較して試料が厚いため，超高圧電子顕 微鏡を用いないと良質な像が得られない。この写真から， (a)
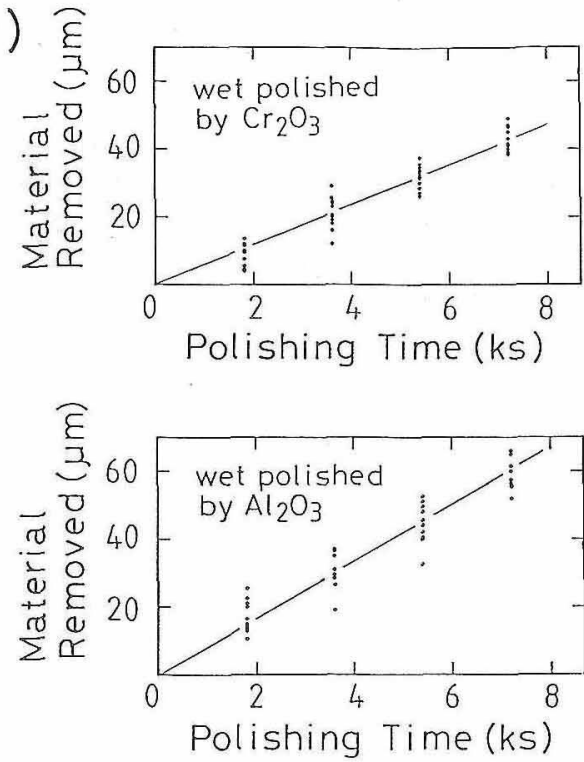

(b)
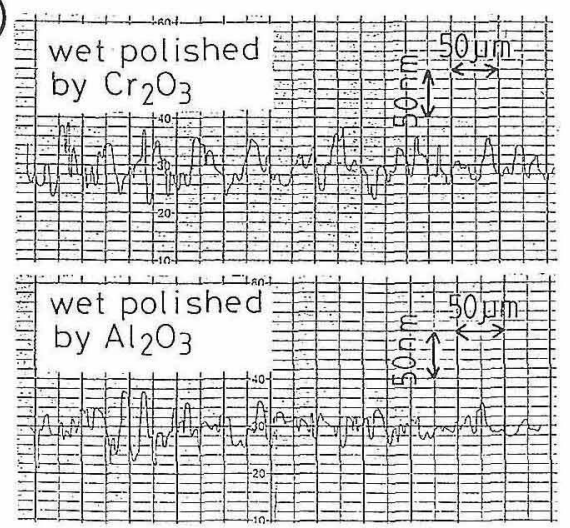

Fig. 1. (a) Polishing rate and (b) surface roughness of AlN polycrystalline specimens wet-polished with $\mathrm{Cr}_{2} \mathrm{O}_{3}$ and $\mathrm{Al}_{2} \mathrm{O}_{3}$ abrasives. Polishing rates are $5.83 \mu \mathrm{m} / \mathrm{ks}$ and $8.29 \mu \mathrm{m} / \mathrm{ks}$, respectively. A maximum of the surface roughness is less than $100 \mathrm{~nm}$ in both cases.

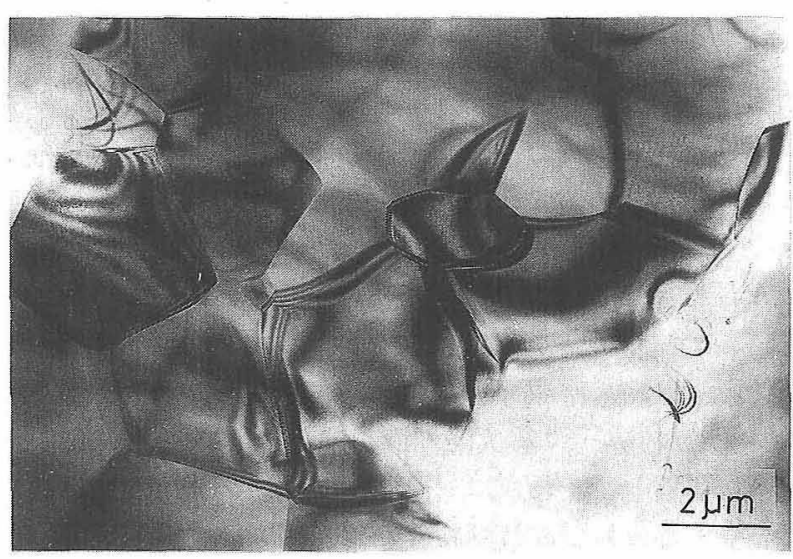

Fig. 2. TEM micrograph of bulk structure of a polycrystalline AIN. The grain size is about $3 \mu \mathrm{m}$ and lattice defects such as dislocation and stacking fault are not found in grains.

表面から約 $0.3 \mu \mathrm{m}$ の厚及で高密度の転位層が生成し，転 位の一部はすべり運動を起こしてさらに深い部分になで侵 


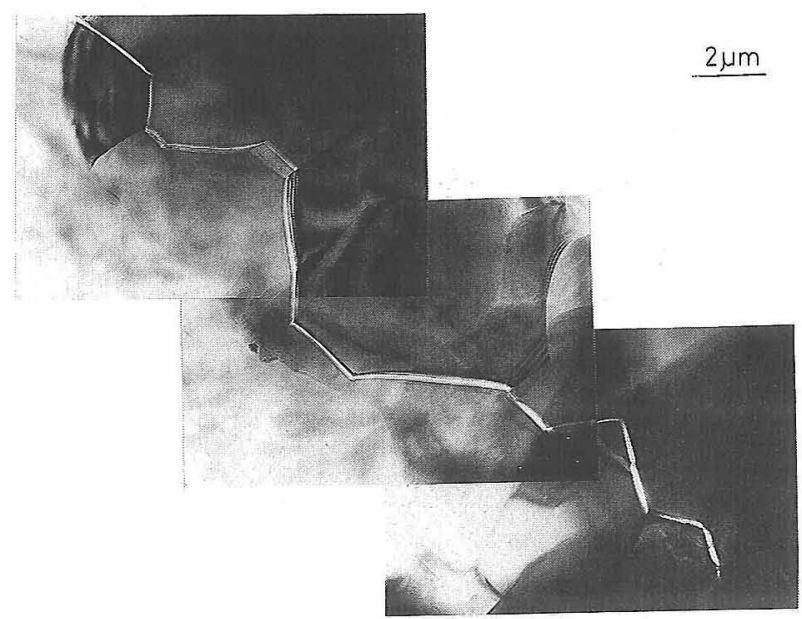

Fig. 3. Microcrack in a thin foil AlN. Note that a fracture do minantly occurs at grain boundaries.

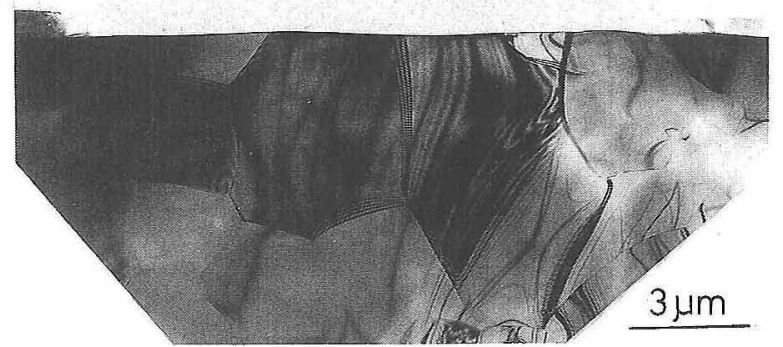

Fig. 4. Artefact of ion thinning in cross-sectional observation of a polished surface. A surface layer is preferentially attacked and etched by argon beam.

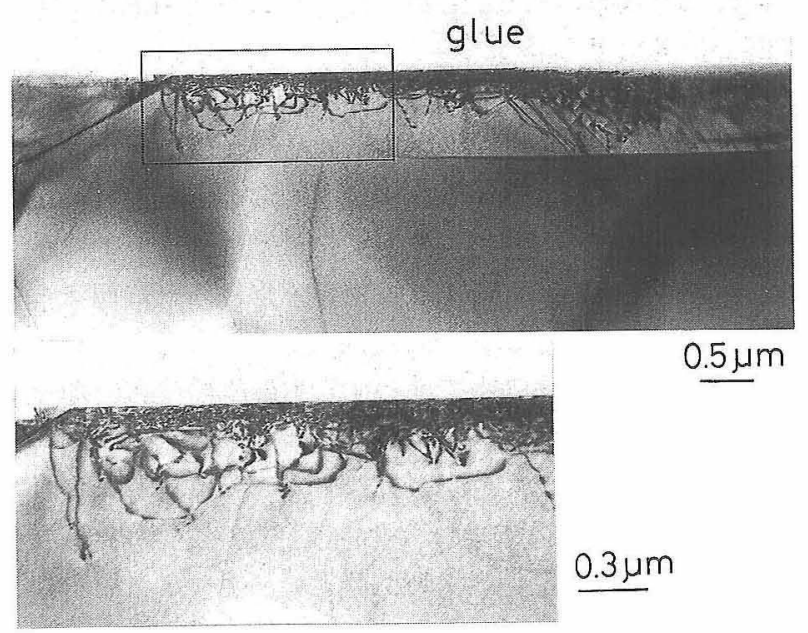

Fig. 5. Cross-sectional view of $\mathrm{Cr}_{2} \mathrm{O}_{3}$ wet-polished surface. A glue is a marker of the real surface. An enlarged image shows that the surface layer is heavily dislocated and some dislocations propagate to a deeper region.

入していることが分る。したがって，この高密度転位層の 存在により基板表面近傍での熱伝導は著しく低下している

\section{ことが予想される。}

このような表面から内部に伝播する転位の性質を決定す るため種々の回折波で観察を行った。図 6 , 図 7 は図 5 からわずかに横に外れた視野であるが，最表面は削り取ら れ伝播した転位のみが見られる。

図 6 に括いて，(b) $g=00 \cdot \overline{2}$ 及び(c) $g=01 \cdot 3 て ゙$ 転位像が 消失しているためバーガースベクトルは $b= \pm a[10 \cdot 0]$ (4

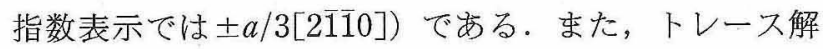
析15)を用いて転位線の方向を決定すると（図 8 (a)), $u=\left[\begin{array}{ll}1.000 & 0.088 \cdot \overline{0.005}\end{array}\right] \fallingdotseq[10 \cdot 0]$ と底面上に存在し16)， $b$ といがほぼ平行であるためらせん成分が強い転位である ことが分かる(4 指数表示では u//[2110]，図 8(a)中には黒 丸で示した)。

一方，図 7 における半ループにおいては，バーガース

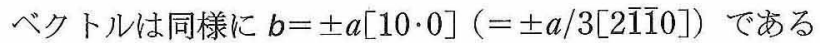
が，図7(a)から明らかなように転位線は底面に乗ってい ない。この転位の存在する結晶面を決定するために図 7 (a) 右図の模式的に示したような三つの部分に分割し， 同様にトレース解析を行った（図 8(b))。この図から転位 線は $(01 \cdot 0)$ 面 ((0110) 面) に存在し， $b$ がこの面に平

(a)

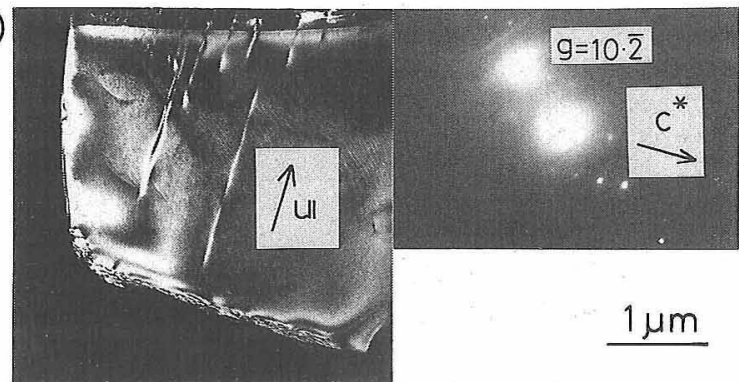

(b)
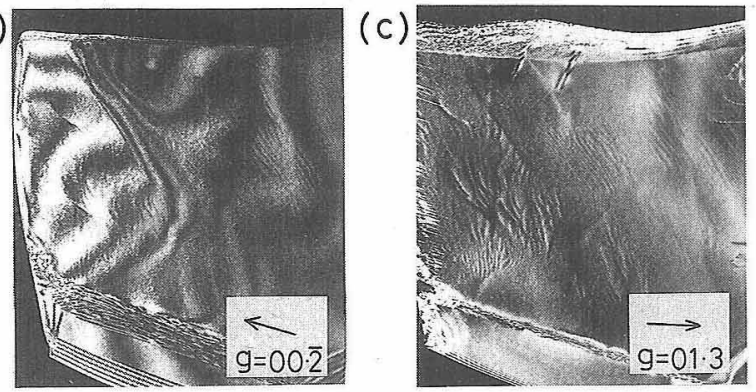

(d)

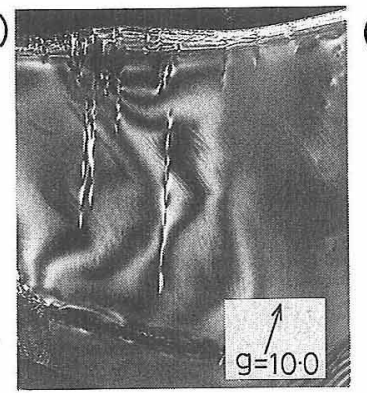

(e)

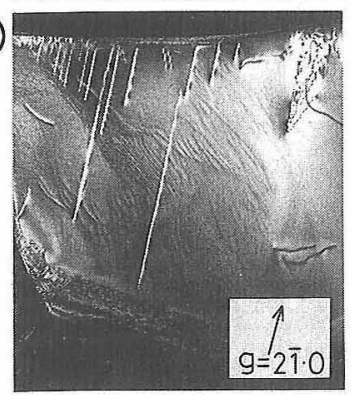

Fig. 6. A series of dark-field images of dislocations near the surface polished with $\mathrm{Cr}_{2} \mathrm{O}_{3}$ abrasive. The Burgers vector is determined to be $b=a[10 \cdot 0]$ from Figs. (b) and (c). The dislocation line lays on the basal plane since the trace is almost perpendicular to $c^{*}$-direction in Fig. (a). A detail of trace analysis of the dislocation line $u$ is illustrated in Fig. 8(a). 

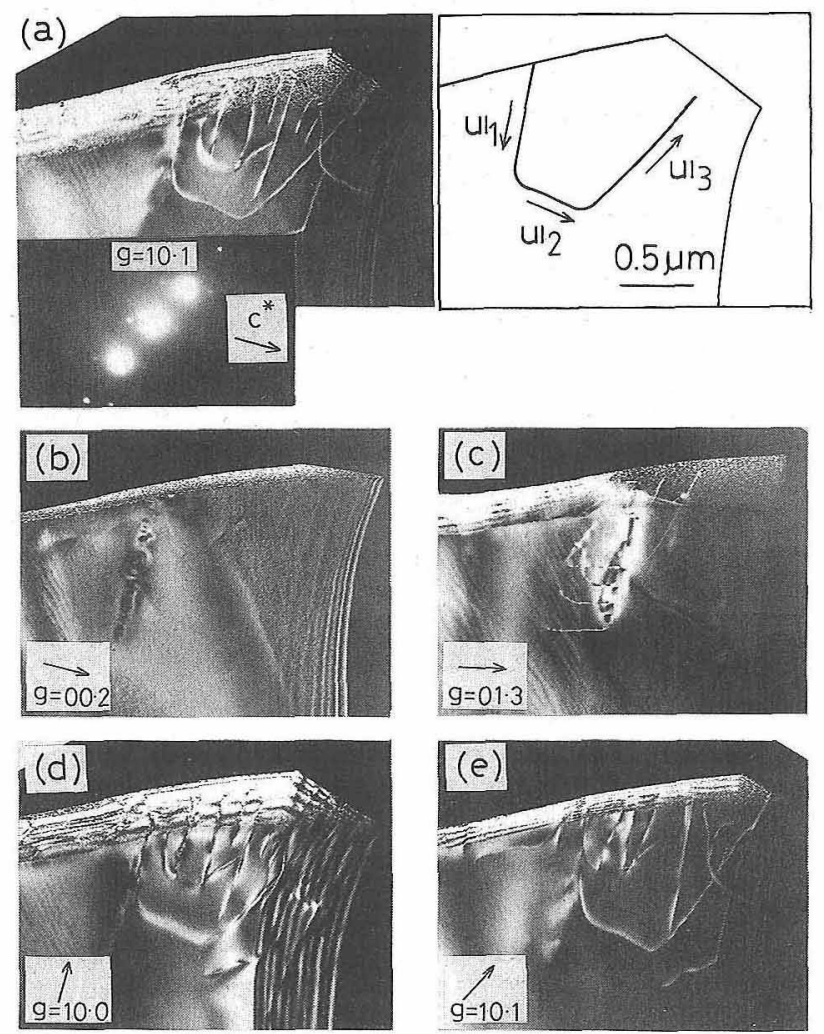

Fig. 7. Another type of dislocations propagating from the surface layer. The Burgers vector is $b=a[10 \cdot 0]$ similarly, but the slip plane is not the basal plane. A half loop is separated into three segments $u_{1}, u_{2}$ and $u_{3}$ which are analyzed in Fig. 8(b).

行であるためすべり運動を起こしていることが分かる。

したがって，これらの転位はいずれも底面上での最短の 格子ベクトルに相当する $b=a\langle 10 \cdot 0\rangle$ 型のバーガースベク トルを持つが，転位線が前者は底面（basal plane，(00・1) 面）に，後者は円筒面（prismatic plane, $\{01 \cdot 0\}$ 面）に存 在する。つまり, $\mathrm{AlN} の \mathrm{Cr}_{2} \mathrm{O}_{3}$ 砥粒研磨に扔いては最低 2 種類のすべり系が活動することが結論される。

しかしながらここの転位の運動は最表面に露出した 1 個の結晶粒に限られ，それ以下の粒には伝播しない。図 9 の観察例では一つのすべり系の久が活動し，研磨表面に起 源を持つ転位の張り出が生じている。 しかし結晶粒界に達 した転位は部分転位に分解せず，もとのバーガースベクト ルを保ったます粒界面上で活動を停止する17),18)。更に下 部の結晶粒に伝播するためには上下の結晶粒ですべり方向 が㧍抢よそ一致する必要が劣り19)，この場合は粒界上に 拘束された部分が新たな転位源として下部に作用するだけ の駆動力が与元られなかったことが分かる。

\section{$3.3 \mathrm{Cr}_{2} \mathrm{O}_{3}$ 砥粒で研磨した試料の研磨方向からの観察 結果}

断面観察に扔いて良好な薄膜試料の作製は困難なため非 常に限られた視野しか観察することができず，研睰面全体 をキャラクタリゼーションしていない危険性がある. 一 方, 研磨面方向からの観察で深さ方向の情報は限られる が，広範囲な領域を観察することがでさる。このため，2
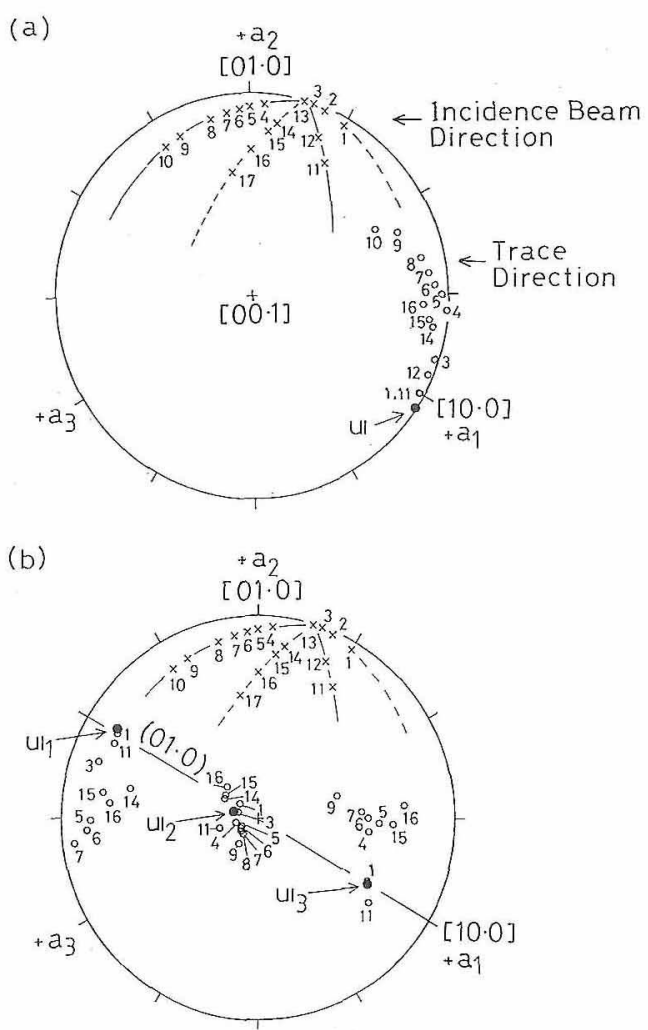

Fig. 8. (00-1) stereograms corresponding to (a) Fig. 6 and (b) Fig. 7. The incidence beam directions are plotted by crosses and the trace directions of a dislocation are plotted by open circles. Photos (a)-(e) in Fig. 6 correspond to Points 4, 2, 17, 16, 11 in Fig. 8(a), while photos (a) -(e) in Fig. 7 correspond to Points 6 , 13, 17, 5, 15 in Fig. 8(b), respectively. The directions of dislocation line $u, u_{1}, u_{2}$ and $u_{3}$ calculated by the least-square method from 17 photographs are indicated by closed circles.

方向功ら観察を相補的に行うことにより研磨最表面を全 体的に把握できる。

図10には $\mathrm{Cr}_{2} \mathrm{O}_{3}$ 砥粒で研磨した試料の研磨方向からの 観察結果を示した。大半は結晶粒 Aのように非常に高密 度の転位（>〜1014 $\mathrm{m}^{-2}$ ) 唯導入されていた。ところがま れに結晶粒 Bのようにほとんど転位が存在しない粒がす ぐそばに隣接し，必ずしもこの塑性変形は均一に起こって いない。

また，1個の結晶の中でも必ずしも転位の分布は均一で はない場合む観察され，特に粒界近傍で局所的に転位密度 が高い傾向を示した．図11にはほとんぞ転位が導入されて いない結晶粒の暗視野像を示すが，上側の粒界から転位が 生成・伝播し，結晶粒界が転位源として㗢くことを示唆し ている、たたし，他の粒界近傍では転位が見られないこと からすべての粒界が転位源として作用するわけではないよ うである。

これらの観察結果から AlN の研磨による転位生成には 不均一性が伴うことが分かり，これは後述するように自由 表面及び結晶粒界が転位源として働くことに関連する。

$3.4 \mathrm{Al}_{2} \mathrm{O}_{3}$ 砥粒で研磨した試料の TEM 観察の結果 $\mathrm{Al}_{2} \mathrm{O}_{3}$ 砥粒で研磨した試料についても断面観察及び研磨 

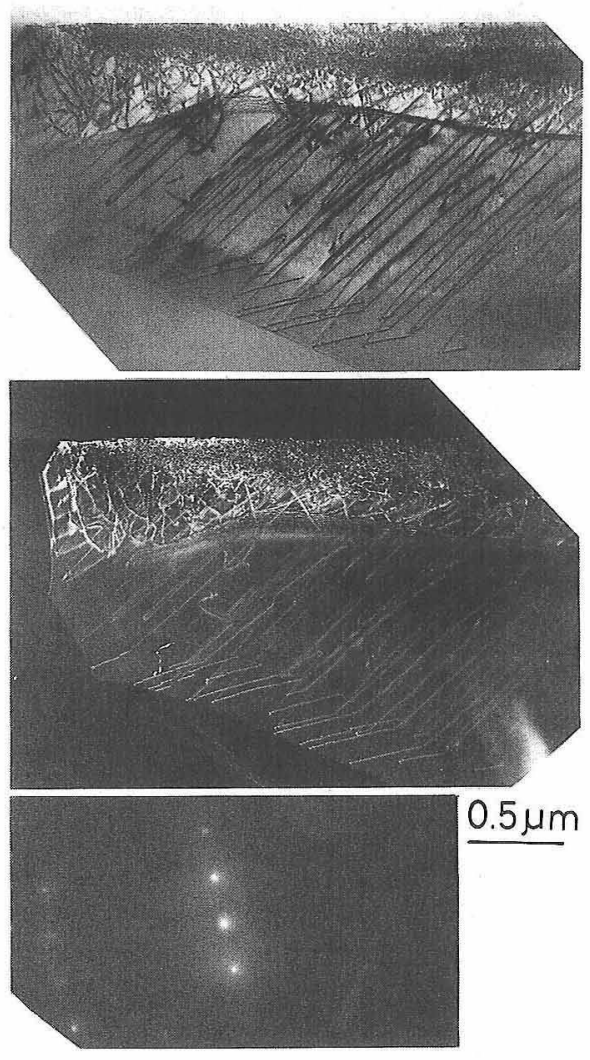

Fig. 9. Bright-field and dark-field images of dislocations proparating to a deeper region. Note that the slip motion is suspended at a grain boundary and a damage is only limited in a grain which exposes to the surface.

方向からの観察を行った結果, $\mathrm{Cr}_{2} \mathrm{O}_{3}$ 砥粒で研磨した試料 上ほぼ同じ結果が得られた（図12）。

(1) 最表面から約 $0.5 \mu \mathrm{m}$ の領域には高密度の転位が導 入され，転位の一部は更に梁くなで及ぶ(図12(a))。

（2）大半の結晶粒には高密度の転位が導入されるが(図 12 (b)中の結晶 A)，なれに転位をほとんど含まない結晶 も存在する (結晶 B).

（3）1個の結晶粒の中でも転位の分布が均一でない場 合が率り，粒界部に転位が集中する傾向が見られる（図 $12(\mathrm{c}))$.

$\mathrm{Al}_{2} \mathrm{O}_{3}$ は $\mathrm{Cr}_{2} \mathrm{O}_{3}$ と比較して更に硬質の砥粒である.とこ ろが両者で研磨した試料に扔いて表面損傷の程度に差異が 見いだされなかったことは，AlN 自身が非常に軟質材料 であるのでそのいずれの研磨に扔いても機械的除去作用が 支配的であったためと考えられる.

\section{4. 考察}

ウイスカーなどの久陥を含まない結晶中に転位を発生さ せるためには理想強度に匹敵する応力を加える必要がめ り，実際の結晶性材料の变形にはすでに存在する転位がそ の増殖に関与していると考光られてきた（Frank-Read source，以下，F-R 源と略す)。ところが本観察から AlN の湿式研磨による塑性挙動は以下の二つの格子欠陥

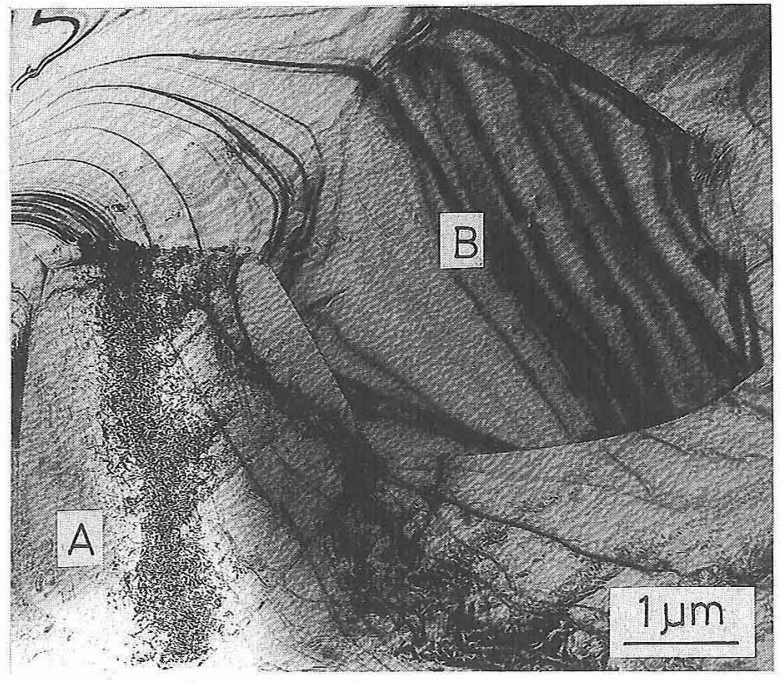

Fig. 10. A plane-view of $\mathrm{Cr}_{2} \mathrm{O}_{3}$ wet-polished surface. Most of grains are heavily dislocated as grain A, while it is not in grain B. It suggests that a deformation caused by the polishing is not perfectly homogeneous.

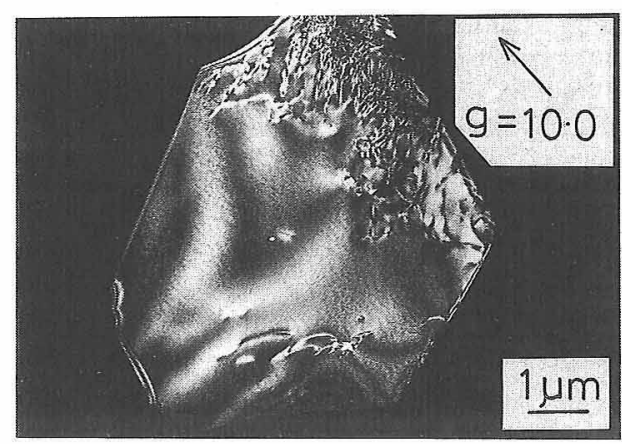

Fig. 11. Dark-field image of $\mathrm{Cr}_{2} \mathrm{O}_{3}$ wet-polished surface from a plane-view direction. Note that a high density of dislocations are found near a grain boundary.

により影響を受けることが示唆される。第 1 は自由表面 である. 自由表面に抢いては F-R 源を活動させる応力が バルク内の $1 / 2$ であるため 20 , 転位の生成・増殖が優先的 に抢こる (表面転位源21) 24) $)$ 。第 2 は結晶粒界であり, 自由表面と同様の効果が考えられる。

転位の基本的性質として転位線は結晶内部に端を持つこ とができないため, ループとして閉じるが結晶表面（自由 表面, 結晶粒界)に両端が拔け出なければならない25)。こ のため研磨中に応力が加わった場合も突然に結晶中に転位 は発生し得ず，まず自由表面，結晶粒界から半ループが導 入されることが考えられる，次に，この転位は底面及び円 筒面をすべり面とすることができるため，F-R 源として 作用する。つまり両方の格子面での交差すべりを繰り返す ことによりその数を増す。このため最終的には，最初に転 位が導入された部分の近傍では転位が加速的に増殖し，転 位分布に不均一性が生じることが考えられる。

現在, AlN は大型の単結晶を作製する技術が確立され 


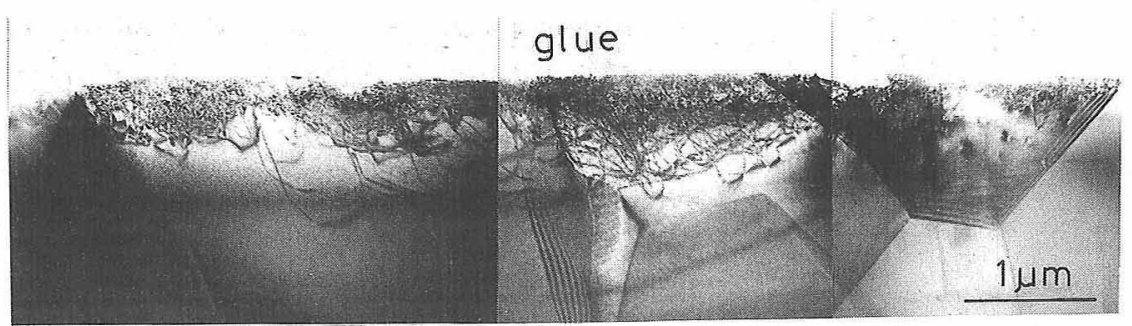

(a)

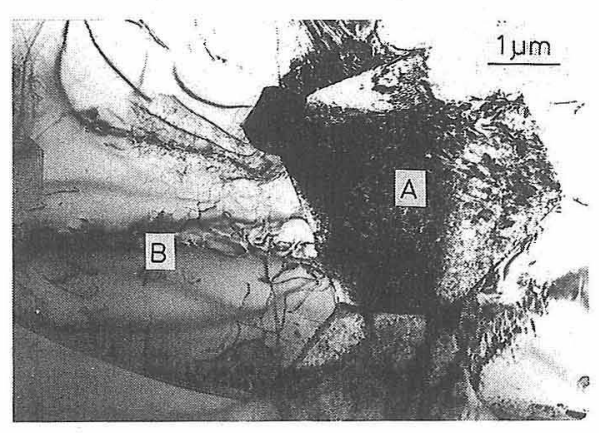

(b)

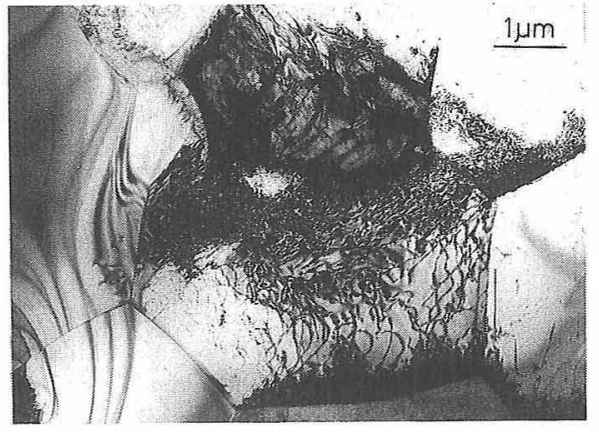

(c)

Fig. 12. TEM micrographs of $\mathrm{Al}_{2} \mathrm{O}_{3}$ wet-polished surface.

(a) Cross-sectional observation showed that no significant difference is essentially found in comparison with that of $\mathrm{Cr}_{2} \mathrm{O}_{3}$ wet-polished sample (Fig. 5) although the dislocation layer is slightly thicker.

(b) A plane-view observation showed that most of grains are heavily dislocated as shown in grain A but a few grains are almost dislocation-free (grain B).

(c) The distribution of dislocation in a grain is occasionally inhomogeneous, suggesting that a grain boundary acts as a dislocation source.

ていないため,その塑性(転位論)の研究は Delavignette ら 16$)$ 以来ほとんど進展していないといってよい。このため転位 の増殖開始応力及び方位による異方性などの基礎的データ は不明であるが，A1Nの転位の生成による研磨損傷を避 けるためには研磨時に個々の結晶粒に加わる応力が増殖開 始応力以下に設定しなければならないことが指摘される. つまり，完全結晶において理想強度に匹敵する応力に達す るなで結晶粒内には転位が発生することはないが，自由表 面もしくは結晶粒界が転位源として働くことから，一度こ こから転位が導入されるとF-R 源として作用し, 転位の 増殖，伝播が加速度的に起こると考えられる。

\section{5. 結 論}

$\mathrm{Al}_{2} \mathrm{O}_{3}$ 又は $\mathrm{Cr}_{2} \mathrm{O}_{3}$ 砥粒を用いた $\mathrm{AlN}$ 多結晶体の湿式研 磨に拈いては表面粗さが100 $\mathrm{nm} R_{\max }$ 程度の平滑面を高効

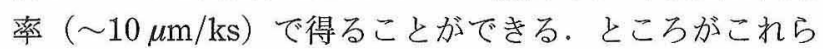
の碈粒による除去は機械的作用が支配的でめるため, 研磨 表面近傍に転位の生成を伴う. 超高王電子顕微鏡を用いた 断面観察及び研磨方向からの観察から以下の結果が得られ た。

(1) $\mathrm{Al}_{2} \mathrm{O}_{3}$ 及び $\mathrm{Cr}_{2} \mathrm{O}_{3}$ のいずれの砥粒においても表面 近傍に高密度の転位で構成される加工変質層が形成され

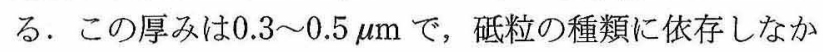
った。

（2）この転位は自由表面及び結晶粒界に起源を持つ. 一度, 転位が導入されると Frank-Read 源として作用し,
底面と円筒面の交互すべりを繰り返すことにより急激に密 度を増す。このため転位分布に不均一性が生じる。

（3）一部の転位はすべり運動により更に深い領域まで 伝播する。ところが結晶粒界が障害として働き，損傷を受 ける粒は最表面に露出した 1 個に限られる.

この転位層の存在により表面近傍での熱伝導率が著しく 低下していることが予想され, 現在, 酸, アルカリ, 温水 中での化学的除去作用を加味した無歪研磨法を検討してい る.

謝辞 タイホー工業(侏) - 河田研治博士には AIN 試料及 び研磨板を提供して頂いた。東京大学生産技術研究所・石田洋一 教授には転位と粒界の関連について, 東京大学物性研究所・竹内 伸教授には wurtzite 結晶におけ引る転位論について有意義な示唆を 頂いた．また，本研究は科学技術庁振與調整費及び文部省科学研 究費の補助によることを付記する。

\section{文 献}

1）池田正義, 材料科学, 27, 159-71 (1990).

2）篠㠃和夫, 安斎和雄, 岩瀬蝪男, 柘植章彦, 日本金属学会 会報, 25, 253-59 (1986).

3）篠嵭和夫, 水谷惟恭, 澤田 豊, セラミックス, 25 105559 (1990).

4) G. A. Slack, J. Phys. Chem. Solids, 34, 321-35 (1973).

5) G. A. Slack, R. A. Tanzilli, R. O. Pohl and J. W. Vandersande, J. Phys. Chem. Solids, 48, 641-47 (1987).

6) 酒井利和, 栗山正明, 犬飼 隆, 木島 剛, 窒協, 86, 174-79 (1978).

7）倉本信行, 谷口人文, 沼田良彦, 麻生 巧, 窯協, 93, 517-22 (1985).

8) M. F. Denanot and J. Rabier, J. Mater. Sci., 24 1594-98 (1989). 
9） S. Hagege，田中俊一郎，石田洋一，日本金属学会誌，52 1192-98 (1988).

10) S. Hagege, Y. Ishida and S. Tanaka, J. Phys. Colloq., 49C5, 189-94 (1988).

11）岡本正英，荒川英夫，大橋正文，荻原 覚，セラミックス 論文誌, 97, 1478-85 (1989)。

12）須賀唯知，鈴木重信，宮沢薰一，精密工学会誌，55，224753 (1990).

13）岡野 清, 高橋 裕, 須賀唯知, 鈴木重信, 河田研治, 精 密工学会春季大会学術講演会論文集 (1991) pp. 519-20.

14）日本電子顕微鏡学会関東支部学術講演予稿集（一断面観察 を中心として一) (1987) pp. 15-24.

15) P. B. Hirsch, A. Howie, R. B. Nicholson, D. W. Pashley and M. J. Whelan, "Electron Microscopy of Thin Crystals", Butterworths (1965) pp. 311-15.

16) P. Delavignette, H. B. Kirkpatrick and S. Amelinckx, $J$. Appl. Phys., 32, 1098-1100 (1961).

17) Y. Ishida and M. H. Brown, Acta Met., 15, 857-60 (1967).
18) Y. Ishida, Trans. Jpn. Inst. Met., 11, 107-12 (1970).

19）鈴木秀次, “転位論一その金属学への応用”, 日本金属学会 編, 丸善 (1977) pp. 122-24.

20）丸川健三郎, “転位論一その金属学への応用”, 日本金属学 会編，丸善（1977） p. 64.

21） J. J. Gilman and W. G. Johnston, "Dislocations and Mechanical Properties of Crystals", Ed. by J. C. Fisher, W. G. Johnston, R. Thomson and T. Vreeland, Jr., Wiley (1957) pp. 116-63.

22) T. Suzuki, "Dislocations and Mechanical Properties of Crystals", Ed. by J. C. Fisher, W. G. Johnston, R. Thomson and T. Vreeland, Jr., Wiley (1957) pp. 215-31.

23) T. Tabata, H. Fujita and H. Kusuhashi, J. Phys. Soc. Jpn., 45, 1320-26 (1978).

24）北島貞吉, 篠原和敏, 日本金属学会会報，25，980-87 (1986).

25）鈴木秀次，“転位論入門”，アグネ（1980） p. 27. 